\title{
The Effect of Pulping Process Variable and Elemental Chlorine Free Bleaching on the Quality of Oil Palm Trunk Pulp
}

\author{
Wieke Pratiwi ${ }^{1}$, Andoyo Sugiharto ${ }^{2}$, Susi Sugesty ${ }^{2}$ \\ ${ }^{1}$ Centre for Material and Technical Product, Jl. Sangkuriang 14, Bandung, Indonesia \\ ${ }^{2}$ Centre for Pulp and Paper, Jl. Raya Dayeuhkolot 132, Bandung, Indonesia
}

Received : 21 Desember 2017, Revised : 12 Desember 2018, Accepted : 18 Desember 2018

\section{Pengaruh Variabel Proses Pulping dan Pemutihan Elemental Chlorine Free pada Kualitas Pulp Batang Kelapa Sawit}

\begin{abstract}
Abstrak
Batang Kelapa Sawit adalah bahan baku selulosa non-kayu yang belum banyak digunakan dalam pembuatan pulp dan kertas. Penelitian tentang pemanfaatan Batang Kelapa Sawit (BKS) dari Sabah (Malaysia) dan Lebak (Provinsi Jawa Barat) yang berlimpah untuk produksi pulp menggunakan proses kraft dan soda antrakuinon dengan alkali aktif (AA) kisaran 13-17\% telah dilakukan. Penyerpihan dan proses depithing bahan baku dilakukan sebagai perlakuan awal. Pemutihan pulp dilakukan menggunakan Elemental Chlorine Free (ECF). Analisis bahan baku mencakup sifat fisik dan kimia, serta morfologi serat. Kedua serat BKS dapat diklasifikasikan sebagai serat moderat dengan panjang 1,05-1,37 mm. BKS dari Sabah sangat ruah dengan densitas tumpukan serpih masing-masing $102,16 \mathrm{~kg} / \mathrm{m}^{3}$ untuk yang belum di-depithing dan $62,91 \mathrm{~kg} / \mathrm{m}^{3}$ untuk yang telah di-depithing. Sifat fisik pulp BKS sebanding dengan pulp dari Acacia mangium. Sehubungan dengan kemampuan pemutihan dan sifat fisik, pembuatan pulp BKS dari Lebak menggunakan proses kraft atau soda-antrakuinon dengan AA 15\% adalah kondisi optimal. Depitihing BKS dari Sabah dengan kandungan pith yang tinggi dapat meningkatkan sifat fisik pulp. Pemutihan dengan urutan ODEoDnD untuk pulp BKS dari Sabah memberikan hasil sifat fisik yang memuaskan. BKS dari Sabah memiliki kandungan pith yang tinggi sehingga rendemen pulp yang diputihkan relatif rendah (24,67-26,73\%). Namun, sifat-sifat fisik pulp putih BKS dari Sabah yang belum dan telah di-depithing lebih tinggi dibandingkan SNI Pulp Kraft Putih Kayudaun (LBKP).
\end{abstract}

Kata kunci: depithing, Elemental Chlorine Free, pulp putih, sifat fisik, LBKP

\begin{abstract}
Oil Palm Trunk (OPT) is a non-wood cellulosic raw material which is not yet widely utilized in pulping and papermaking. Research on the utilization of abundant Oil Palm Trunk (OPT) from Sabah (Malaysia) and Lebak (West Java Province) for pulp production was carried out using kraft and soda anthraquinone processes with active alkali (AA) of 13-17\%. The raw material was chipped and depithed as pretreatment. Bleaching of pulp was carried out using Elemental Chlorine Free (ECF) process. Analysis of raw material covered physical and chemical properties, and fiber morphology. Both OPT fibers were classified into the moderate fiber length $(1.05-1.37 \mathrm{~mm})$. Sabah OPT were very bulky with the chips pile density of $102.16 \mathrm{~kg} / \mathrm{m}^{3}$ and $62.91 \mathrm{~kg} / \mathrm{m}^{3}$ for undepithed and depithed OPT, respectively. The physical properties of OPT pulps were comparable to that of Acacia mangium pulp. With respect to the bleachability and physical properties, pulping of Lebak OPT using kraft or soda-anthraquinone process with AA of $15 \%$ were considered as optimum condition. Depithing on Sabah OPT with high pith content could increase physical properties of pulp. ODEoDnD bleaching sequence on pulps from Sabah OPT gave satisfactory results with respect to the physical properties. Since Sabah OPT had a high pith content, the yields of bleached pulp were relatively low (24.67-26.73\%). However, the physical properties of the undepithed and depithed Sabah OPT bleached pulp were higher compared to those of the SNI of Leaf Bleached Kraft Pulp (LBKP).
\end{abstract}

Keywords: depithing, Elemental Chlorine Free, bleached pulp, physical properties, LBKP 


\section{Introduction}

Indonesia is a palm oil exporting country with an ever increasing value, from 4.11 million tonnes in 2000 became 20.58 tonnes in 2013 (Direktorat Jenderal Perkebunan, 2014). The increase in production of palm oil, the more waste is generated (Awalludin et al., 2015; Hambali and Rivai, 2017). The waste or residue of oil palm plantations consists of leaves from pruning activities, palm stems from replantations programs, as well as empty fruit bunches, kernel shell and fiber from oil processing mill (Aljuboori, 2013). Fiber and palm kernel shell are utilized as fuel in steam power plant in palm oil mills (Aziz et al., 2017). The leaves and trunks are usually left in the field (Joedodibroto, 2000; Garcia-Nunez et al., 2016), which may cause various problems if it is not managed properly.

Oil Palm Trunk (OPT) is a type of waste from oil palm plantations, which is usually left in the field to rot and may untidy place and hamper movement of the worker (Daud and Law, 2010). Currently, oil palm plantation residue is available in quite considerable quantities due to the high expansion rate of oil palm plantation (Risdianto, Kardiansyah and Sugiharto, 2016). The area of oil palm plantation in Indonesia increased significantly from 4.2 million hectares in the year of 2000 became 10.5 million hectares in 2013 . In 2014, the total area of oil palm plantations in Indonesia was approximately 11 million hectares (Direktorat Jenderal Perkebunan, 2014). During harvesting, every hectare of palm plantation yields over 70 tones of dry trunk as biomass waste (Mamiński et al., 2016).

As a source of lignocellulosic material, OPT is less expensive compared to wood. Utilizing OPT as a raw material to produce value-added products will not only reduce the overall costs of pulp production, but will also increase economic return of oil palm plantation (Sulaiman et al., 2012). OPT is a non-wood cellulosic raw material which is not yet widely utilized in pulping and paper making (Erwinsyah, Afriani and Kardiansyah, 2015). Due to the limited characteristic of fibers, an attempt has been made to utilize OPT as a substitute for wood fiber in pulping. Research on the possibility of OPT as a raw material for pulp using environmentally friendly process is reported in this paper.

Pulping was carried out using the kraft and the soda anthraquinone processes. Then bleaching of pulp was carried out using the Elemental Chlorine Free (ECF) process. Evaluation of pulp handsheets was done to observe the quality of pulp. Before pulping the raw material was subjected to chipping and depithing as pretreatment. Analysis of raw material covered physical and chemical properties, and also fibre morphology.

\section{Materials and Method}

\section{Raw Materials}

Oil Palm Trunk used in this experiment were originally from Sabah (Malaysia) and Lebak (Pandeglang, West Java Province). The OPT from Sabah was received in the form of 20 disks cut from 5 different oil-palm trees. Each tree was cut into four parts of the trunk, i.e:Bottom (B), Middle Bottom (MB), Middle Top (MT), and Top (T), with the diameter in the range of $35-45 \mathrm{~cm}$ and thickness of $5-8 \mathrm{~cm}$. While raw material from Lebak was received as its original condition.

\section{Method of Experiment}

Pulping was conducted in two methods, i.e.: the Kraft process for Sabah OPT, and the Kraft and the Soda AQ processes for Lebak OPT (Figure 1). Bleaching was conducted in the $O \mathrm{ODE}_{\mathrm{o}} \mathrm{D}_{\mathrm{n}} \mathrm{D}$ sequence which was elemental chlorine free (ECF). Determination of physical and optical properties were applied on bleached pulp and unbleached pulp.

\section{Preparation of Feedstock}

All types of raw material were chipped to get feedstock for pulping. Sabah OPT was prepared in two kinds of feedstock: undepithed and depithed, then called as SU and SD, respectively (Figure 1). The SD feedstock was obtained from mixing of equal portions of depithed fibres, i.e. $25 \%$ each of B, MB, MT and T Sabah OPT. So, the effect of the absence of pith in feedstock could be evaluated. Preparation of feedstock from Lebak was only for undepithed material which consists of bottom, middle and top parts of trunk.

\section{Analysis of Morphological, Physical and Chemical Properties of Raw Material}

Analysis of morphological, physical and chemical properties of raw materials were 


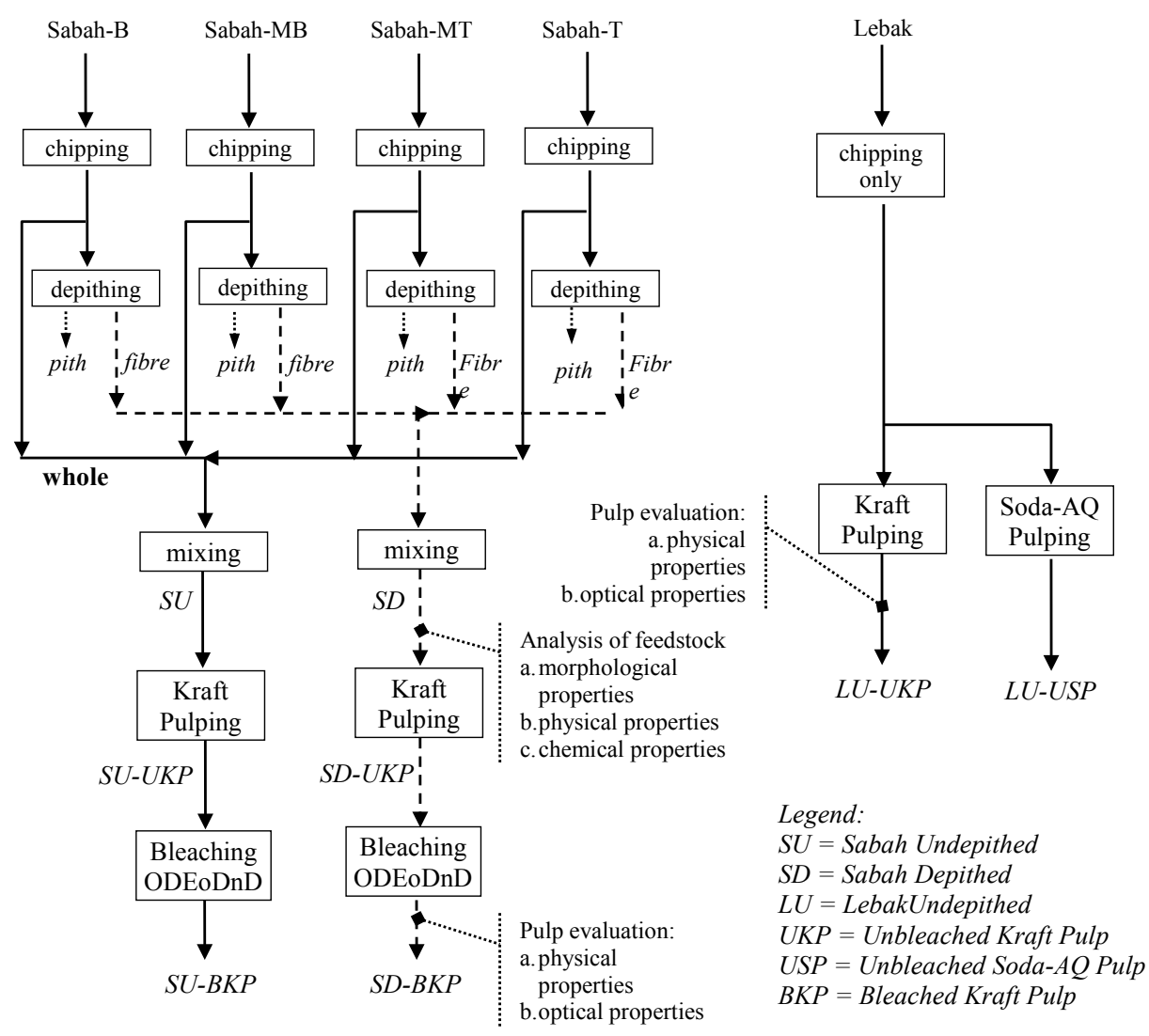

Figure 1. Procedure of Experiment

conducted according to the Indonesian National Standard (SNI). The chemical analysis of depithed and undepithed feedstock included lignin, holocellulose, alpha cellulose, ash, extractives, and pentosan contents. The solubility in $1 \% \mathrm{NaOH}$, cold water and hot water were also determined according to SNI.

\section{Pulping and Bleaching}

\section{a. Pulping}

The kraft (sulfate) and the soda anthraquinone processes were used by varying the active alkaliof 13\%, 15\% and 17\% (Table 1). The kraft process was used for feedstock of undepithed and depithed Sabah OPT (SU and SD, Figure 1). The kraft and the soda anthraquinone processes were used for undepithed OPT from Lebak (LU, Figure 1). Pulping processes were conducted in a three litre rotating digesters circulated in heated air. Pulp was then washed and screened prior to the determinations of the screen yield and Kappa number $(\mathrm{KN})$.

b. Bleaching of Pulp

Elemental Chlorine Free bleaching process using five stages of $O D E_{0} D_{n} D$ sequence (Table 2) was applied to pulp obtained from Sabah OPT.

\section{Evaluation on Unbleached and Bleached Pulps}

The unbleached and bleached pulps from Sabah (SU-UKP and SU-BKP, and SD-UKP and SD-BKP) were beated separately in a Niagara Beater.The results were made into pulp handsheets and tested for their physical and optical properties acccording to the Indonesian National Standard (SNI). The freeness of pulp was tested using Schopper Riegler (SR) Freeness Tester.

Pulp from Lebak OPT was treated in the same way as those for Sabah OPT. The freeness of the pulp from Lebak OPT was tested using Canadian Standard Freeness Tester. 
Table 1. Pulping Conditions of Oil-Palm Trunk

\begin{tabular}{clcc}
\hline No & Process Variable & Kraft & Soda AQ* \\
\hline 1. & Active alkali $\left(\%\right.$ as $\left.\mathrm{Na}_{2} \mathrm{O}\right)$ & $13 ; 15 ; 17$ & $13 ; 15 ; 17$ \\
2. & Sulfidity $\left(\%\right.$ as $\left.\mathrm{Na}_{2} \mathrm{O}\right)$ & 25 & - \\
3. & Anthraquinone $(\mathrm{AQ})(\%)$ & - & 0.1 \\
4. & Liquor ratio & $1: 4$ & $1: 4$ \\
5. & Maximum temperature $\left({ }^{\circ} \mathrm{C}\right)$ & 170 & 170 \\
6. & Time to reach maximum temperature (hours) & 2 & 2 \\
7. & Time at maximum temperature (hours) & 1.5 & 1.5 \\
\hline
\end{tabular}

*only for Lebak OPT

Source: Pratiwi, et al., (2016)

Table 2. The Bleaching Process Conditions of SU-UKP and SD-UKP

\begin{tabular}{|c|c|c|c|c|c|c|c|}
\hline \multirow[t]{2}{*}{ No. } & \multirow[t]{2}{*}{ Process Variables } & \multirow{2}{*}{$\begin{array}{l}\text { Oxygen } \\
\text { Stage } \\
\text { (O) }\end{array}$} & \multirow{2}{*}{$\begin{array}{l}\text { Chlorine- } \\
\text { dioxide } \\
\text { Stage } \\
\text { (D) }\end{array}$} & \multirow{2}{*}{$\begin{array}{c}\text { Extraction- } \\
\text { oxygen } \\
\text { Stage } \\
\text { (Eo) }\end{array}$} & \multicolumn{2}{|c|}{$\begin{array}{l}\text { Chlorine-dioxide and } \\
\text { Neutralization Stage } \\
\text { (Dn) }\end{array}$} & \multirow{2}{*}{$\begin{array}{l}\text { Chlorine } \\
\text {-dioxide } \\
\text { Stage (D) }\end{array}$} \\
\hline & & & & & $\mathrm{D}$ & $\mathrm{n}$ & \\
\hline 1. & $\mathrm{O}_{2}$ (pressure in atm) & 6 & - & 6 & - & - & - \\
\hline 2. & $\mathrm{MgSO}_{4}(\%)$ & 0.5 & - & - & - & - & - \\
\hline 3. & $\mathrm{ClO}_{2}$ (as active chlorine) & - & $0.22 \mathrm{KN}$ & - & - & - & - \\
\hline 4. & $\mathrm{ClO}_{2}(\%)$ & - & - & - & 1 & - & 0.5 \\
\hline 5. & $\mathrm{H}_{2} \mathrm{SO}_{4}(\%)$ & - & 0.4 & - & - & - & 0.35 \\
\hline 6. & $\mathrm{NaOH}(\%)$ & - & - & 2 & 0.35 & 0.2 & - \\
\hline 7. & Consistency (\%) & 10 & 10 & 10 & 10 & 10 & 10 \\
\hline 8. & Temperature $\left({ }^{\circ} \mathrm{C}\right)$ & 100 & 70 & 70 & 75 & 75 & 75 \\
\hline 9. & Time (minutes) & 60 & 60 & 60 & 120 & 10 & 150 \\
\hline
\end{tabular}

Note : In the Dn-Stage, chlorine dioxide stage was followed by neutralization without any washing in between

Source: Pratiwi, et al., (2016)

\section{Results and Discussion}

\section{Properties of Feedstock}

The undepithed Sabah OPT (SU) consisted of fibres and pith. The fibre contents of the bottom, middle bottom, middle top, and top parts of Sabah OPT were $59.68 \%, 55.48 \%, 62.50 \%$ and $50.64 \%$, respectively (Table 3). It means that more than $50 \%$ of the raw material might be utilized as the feedstock for pulping. On the other hand, pith consisted of parenchyma cell, which had to be removed before pulping since it might cause more chemical consumption for pulping (Pratiwi, Sugiharto and Sugesty, 2001).

\section{Physical and Morphological Properties of Feedstock}

The physical and morphological properties of feedstock are shown in Table 3. Fiber from
Sabah OPT and Lebak OPT could be classified into the moderate fibre length ranging from $1.05 \mathrm{~mm}$ to $1.37 \mathrm{~mm}$. OPT were very bulky as shown by the chips pile density of $102.16 \mathrm{~kg} / \mathrm{m}^{3}$ for undepithed Sabah OPT and $62.91 \mathrm{~kg} / \mathrm{m}^{3}$ for depithed one. These values are lower compared to chips pile density of Acacia mangium (133$\left.162 \mathrm{~kg} / \mathrm{m}^{3}\right)$ and chips pile density of pine (177$244 \mathrm{~kg} / \mathrm{m}^{3}$ ) (IRDCI, 1999). The higher the chips pile density is, the higher the digester capacity is (Sarwar Jahan, Sarkar and Rahman, 2017). Trema orientalis has been found as the fastest growing wood species suitable for pulping. However, the basic wood density of $T$. orientalis is low, which consequently decreases digester yield. On the other hand, basic wood density of bamboo is quite high. Optimum pulping conditions of these raw materials were similar. Therefore, mixed pulping of $T$. orientalis with bamboo can compensate digester yield. In this study, bamboo and $T$. orientalis chip mixtures were kraft cooked 
and the resulted pulp and paper properties were investigated. Cooking was carried out for five different chip mixtures $(0,25,50,75$ and $100 \%$.

Fibre content of Lebak OPT (an average of $87.88 \%$ ) was significantly higher than that of Sabah OPT (an average of 57.07\%). This difference was understandable as they originated from two different places and possibly two difference variety. Based on the morphological and physical properties of fiber, oil palm trunk had a potency to be used as a raw material for pulp such as Acacia mangium which is commonly used for pulp (Singh et al., 2013).

\section{Chemical Composition of Feedstock}

Chemical composition of undepithed Sabah OPTand depithed Sabah OPT are presented in Table 4. In addition, the chemical composition of Acacia mangium of three years age from Indonesia is also presented. As previously mentioned, data for SU and SD (Sabah OPT) were obtained from the mixtures of equal portions of $\mathrm{B}, \mathrm{MB}, \mathrm{MT}$ and $\mathrm{T}$ parts (Figure 1). As expected, depithing could reduce the lignin content in feedstock, so a reduction in chemicals for pulping might be expected too. Significant reductions were also observed in ash and silicate contents.
A significant increase in holocellulose content was obtained from $68.68 \%$ to $79.67 \%$ for SU and $\mathrm{SD}$, respectively. Even the later was higher than that of Acacia mangium (73.61\%). Although the alpha cellulose content of SD (42.18\%) was still lower than that of Acacia mangium (46.11\%), it increased already from its original value of $33.21 \%$. Moreover, contents of all other impurities such as extractives and soluble compounds decreased significantly. Thus the depithing operation was an effective pretreatment for OPT.

The undepithed Lebak OPT had uniform compositions of main components: lignin, holocellulose, alpha cellulose and pentosan (Table 4). However, the alpha cellulose content of Lebak OPT was lower than that of Acacia mangium $(46.11 \%)$.

Significant differences were observed in the ash contents of undepithed Lebak OPT, i.e.: $2.18 \%, 3.11 \%$ and $6.47 \%$ for bottom, middle and top parts of trunk, respectively. These increases in ash content from the bottom to the top of trunk might related to the fact that ash content in empty fruit bunches was very high (up to 6.68\%) (Pratiwi, Sugiharto and Sugesty, 2001). Similarly, the silicate contents were also increased $1.02 \%$, $1.69 \%$ and $4.52 \%$ from the bottom to the top of trunk. These two properties had to be considered

Table 3. The Physical and Morphological Properties of Raw Material

\begin{tabular}{|c|c|c|c|c|c|c|c|c|c|}
\hline \multirow[b]{2}{*}{ No. } & \multirow[b]{2}{*}{ Parameters } & \multicolumn{4}{|c|}{ Sabah } & \multicolumn{3}{|c|}{ Lebak } & \multirow{2}{*}{$\begin{array}{c}\text { Acacia } \\
\text { mangium }^{*}\end{array}$} \\
\hline & & Bottom & $\begin{array}{l}\text { Middle } \\
\text { Bottom }\end{array}$ & $\begin{array}{c}\text { Middle } \\
\text { Top }\end{array}$ & Top & Bottom & Middle & Top & \\
\hline 1. & $\begin{array}{l}\text { Fibre length (L) (mm) } \\
\text { - Minimum } \\
\text { - Maximum } \\
\text { - Average }\end{array}$ & $\begin{array}{l}0.50 \\
2.42 \\
1.36\end{array}$ & $\begin{array}{l}0.40 \\
2.85 \\
1.22\end{array}$ & $\begin{array}{l}0.37 \\
2.91 \\
1.37\end{array}$ & $\begin{array}{l}0.40 \\
2.76 \\
1.33\end{array}$ & $\begin{array}{l}0.49 \\
2.19 \\
1.24\end{array}$ & $\begin{array}{l}0.38 \\
2.17 \\
1.09\end{array}$ & $\begin{array}{l}0.38 \\
2.01 \\
1.05\end{array}$ & $\begin{array}{l}0.43 \\
1.28 \\
0.79\end{array}$ \\
\hline 2. & Fibre diameter $(\mathrm{D})(\mu \mathrm{m})$ & 37.34 & 36.22 & 29.79 & 29.61 & 27.21 & 23.04 & 17.83 & 13.90 \\
\hline 3. & Lumen $(1)(\mu \mathrm{m})$ & 25.88 & 25.99 & 22.42 & 22.37 & 6.20 & 5.37 & 3.90 & 9.51 \\
\hline 4. & Cell wall thickness $(\mathrm{w})(\mu \mathrm{m})$ & 7.73 & 5.11 & 3.68 & 3.62 & 10.51 & 8.84 & 6.97 & 2.20 \\
\hline 5. & Runkel Ratio (2w/1) & 0.44 & 0.39 & 0.33 & 0.32 & 3.39 & 3.29 & 3.57 & 0.46 \\
\hline 6. & Fibre content $(\%)$ & 59.68 & 55.48 & 62.50 & 50.64 & 85.62 & 85.60 & 89.11 & - \\
\hline 7. & Pith content $(\%)$ & 40.32 & 44.52 & 37.50 & 49.36 & 14.38 & 14.40 & 10.89 & - \\
\hline 8. & Density $\left(\mathrm{kg} / \mathrm{m}^{3)}\right.$ & 244 & 219 & 214 & 197 & - & - & - & 407 \\
\hline 9. & $\begin{array}{l}\text { Chips pile density }\left(\mathrm{kg} / \mathrm{m}^{3}\right) \\
\text { - Undepithed OPT } \\
\text { - Depithed OPT }\end{array}$ & & $\begin{array}{r}102 . \\
62 .\end{array}$ & & & - & $\begin{array}{l}- \\
-\end{array}$ & $\begin{array}{l}- \\
-\end{array}$ & 147.36 \\
\hline
\end{tabular}

*Penelitian Pembuatan Pulp dari Kayu Acacia mangium Berbagai Umur (Research on Pulping of Various Ages of Acacia mangium). Unpublished Technical Report; 1995

Source: Pratiwi, et al., (2016) 
Table 4. Chemical Composition of Oil-Palm Trunk

\begin{tabular}{|c|c|c|c|c|c|c|c|c|}
\hline \multirow[b]{2}{*}{ No. } & \multirow[b]{2}{*}{ Parameters } & \multicolumn{2}{|c|}{ Sabah OPT } & \multicolumn{4}{|c|}{ Lebak OPT, Undepithed } & \multirow{2}{*}{$\begin{array}{c}\text { Acacia } \\
\text { mangium }\end{array}$} \\
\hline & & $\begin{array}{c}\text { Undepithed, } \\
\text { SU }\end{array}$ & $\begin{array}{l}\text { Depithed, } \\
\text { SD }\end{array}$ & Bottom & Middle & Top & $\begin{array}{c}\text { Average } \\
\text { LU }\end{array}$ & \\
\hline 1. & Lignin (\%) & 25.34 & 19.80 & 22.62 & 21.62 & 24.08 & 22.77 & 26.41 \\
\hline 2. & Holocellulose (\%) & 68.68 & 79.67 & 72.95 & 70.88 & 67.26 & 70.36 & 73.61 \\
\hline 3. & Alpha cellulose $(\%)$ & 33.21 & 42.18 & 41.87 & 40.18 & 37.28 & 39.78 & 46.11 \\
\hline 4. & Pentosan $(\%)$ & 25.01 & 26.45 & 23.55 & 23.79 & 23.18 & 23.51 & 20.76 \\
\hline 5. & Extractives (\%) & 2.03 & 0.81 & 2.10 & 2.04 & 3.51 & 2.55 & 3.28 \\
\hline 6. & Ash $(\%)$ & 4.69 & 2.09 & 2.18 & 3.11 & 6.47 & 3.92 & 0.32 \\
\hline 7. & Silicate $(\%)$ & 2.32 & 1.62 & 1.02 & 1.69 & 4.52 & 2.41 & - \\
\hline 8. & $\begin{array}{l}\text { Solubility in } \\
-\quad 1 \% \mathrm{NaOH}(\%) \\
-\quad \text { Cold water }(\%) \\
-\quad \text { Hot water }(\%)\end{array}$ & $\begin{array}{c}31.79 \\
9.97 \\
10.12\end{array}$ & $\begin{array}{c}19.97 \\
2.17 \\
2.48\end{array}$ & $\begin{array}{c}18.56 \\
4.50 \\
6.10\end{array}$ & $\begin{array}{c}21.61 \\
6.34 \\
7.29\end{array}$ & $\begin{array}{c}25.82 \\
8.32 \\
8.59\end{array}$ & $\begin{array}{c}22.00 \\
6.39 \\
7.33\end{array}$ & $\begin{array}{l}13.68 \\
2.10 \\
3.33\end{array}$ \\
\hline
\end{tabular}

Source: Pratiwi, et al., (2016)

Table 5. Results of Sabah OPT Kraft Pulping at Sulfidity of 25\%

\begin{tabular}{clcccc}
\hline No & Samples $\left.^{\#}\right)$ & $\begin{array}{c}\text { Active Alkali } \\
(\%)\end{array}$ & $\begin{array}{c}\text { Total Yield*) } \\
(\%)\end{array}$ & $\begin{array}{c}\text { Screened Yield } \\
(\%)\end{array}$ & $\begin{array}{c}\text { Kappa Number } \\
\text { KN }\end{array}$ \\
\hline 1. & $13 /$ SU-UKP & 13 & 50.36 & 46.84 & 80.55 \\
2. & $15 /$ SU-UKP & 15 & 44.61 & 43.49 & 47.04 \\
3. & $17 /$ SU-UKP & 17 & 43.93 & 43.23 & 24.07 \\
4. & $13 /$ SD-UKP & 13 & 32.89 & 31.37 & 50.40 \\
5. & $15 /$ SD-UKP & 15 & 29.95 & 29.54 & 18.42 \\
6. & $17 /$ SD-UKP & 17 & 28.87 & 28.67 & 14.12 \\
\hline
\end{tabular}

Note: ") see Legend in Figure 1; ") based on the original raw material

Source: Pratiwi, et al., (2016)

in designing chipper and other equipments for feedstock preparation.

\section{Pulping}

Pulping conditions were employed in order to obtain the bleachable grade pulps with Kappa number of about 14-20. Kappa number is a measure of degree of delignification indicating how far the delignification occurs. This means that the lower Kappa number the lower bleaching chemical charge.

The screened yield tended to decrease with the increase of active alkali, both for SU and SD. The screened yield based on the original raw material of SD pulps were much lower (28.67-31.37\%) compared to those of SU pulps $(43.23-46.84 \%)$ due to the depithing process with a depithing yield of $57.07 \%$ (avg).

Results of Sabah OPT kraft pulping are shown in Table 5. To obtain pulp with about the same KN, undepithed Sabah OPT required more active alkali as shown in samples of $15 / \mathrm{SU}-U K P$ and 13/SD-UKP to obtain KN of 47.04 and 50.40 , respectively. On the other hand, a same pulping condition would give a higher $\mathrm{KN}$ from undepithed than that of depithed (compare KN for 13/SU-UKP vs 13/SD-UKP; 15/SU-UKP vs 15/SD-UKP and 17/SU-UKP vs 17/SD-UKP).

Based on the value of $\mathrm{KN}$, pulps from pulping with active alkali of $15 \%$ and $17 \%(15 /$ SD-UKP and 17/SD-UKP) could be classified as bleachable grade pulps. While from undepithed feed stocks, only pulp from 17/SU-UKP was bleachable grade. Even though, the other pulps might be bleached, but they required more chemicals.

By considering the screened yield and Kappa number, the optimum condition for Lebak OPT (Table 6) was pulping with the active alkali of $15 \%$, both for kraft or soda anthraquinone (SA) processes. Pulp obtained from the kraft pulping 
Table 6. Results of Lebak OPT Kraft and Soda-Anthraquinone Pulping

\begin{tabular}{clcccc}
\hline No & Samples $\left.^{\#}\right)$ & $\begin{array}{c}\text { Active Alkali } \\
(\%)\end{array}$ & $\begin{array}{c}\text { Total Yield } \\
(\%)\end{array}$ & $\begin{array}{c}\text { Screened Yield } \\
(\%)\end{array}$ & Kappa Number (KN) \\
\hline 1. & 13/LU-UKP & 13 & 45.96 & 43.08 & 45.10 \\
2. & 15/LU-UKP & 15 & 38.35 & 37.43 & 20.83 \\
3. & 17/LU-UKP & 17 & 36.51 & 36.29 & 16.52 \\
4. & 13/LU-USP & 13 & 41.76 & 39.57 & 28.23 \\
5. & 15/LU-USP & 15 & 39.70 & 38.95 & 17.38 \\
6. & 17/LU-USP & 17 & 37.06 & 36.88 & 13.38 \\
\hline
\end{tabular}

Note: \#) see Legend in Figure 1; ${ }^{*}$ ) based on the original raw material

Source: Pratiwi, et al., (2016)

Table 7. Results of Bleaching of Sabah OPT Pulp

\begin{tabular}{|c|c|c|c|c|c|c|}
\hline \multirow{2}{*}{ No. } & \multirow{2}{*}{ Samples ${ }^{\#}$ ) } & \multicolumn{2}{|c|}{ Kappa Number, KN } & \multirow{2}{*}{$\begin{array}{c}\text { Yield") } \\
(\%)\end{array}$} & \multirow{2}{*}{$\begin{array}{c}\left.\text { Brightness }{ }^{* *}\right) \\
(\% \mathrm{GE})\end{array}$} & \multirow{2}{*}{$\begin{array}{c}\text { Dirt } \\
\left(\mathrm{mm}^{2} / \mathrm{m}^{2}\right)\end{array}$} \\
\hline & & Brownstock & $\mathrm{O}_{2}$ & & & \\
\hline 1. & 13/SU-BKP & 80.55 & 68.26 & 26.73 & 78.00 & 22.90 \\
\hline 2. & 15/SU-BKP & 47.04 & 32.32 & 24.82 & 75.50 & 31.00 \\
\hline 3. & 17/SU- BKP & 24.07 & 14.46 & 24.67 & 73.10 & 20.65 \\
\hline 4. & 13/SD- BKP & 50.40 & 37.28 & 26.49 & 79.20 & 23.50 \\
\hline 5. & 15/SD- BKP & 18.42 & 12.35 & 27.03 & 76.60 & 58.00 \\
\hline 6. & 17/SD- BKP & 14.12 & 9.52 & 26.08 & 76.00 & 33.00 \\
\hline
\end{tabular}

Notes: ${ }^{*}$ ) see Legend in Figure $1 ;{ }^{*}$ ) based on the original raw material; $\left.{ }^{* *}\right)$ determined at initial freeness

Source: Pratiwi, et al., (2016)

with this condition had the screened yield of $37.43 \%$ and $\mathrm{KN}$ of 20.83 , while that from the SA pulping had the screened yield of $38.95 \%$ and $\mathrm{KN}$ of 17.38. Pulps with these value of KN met the requirement for further bleaching process. In term of screened yield and Kappa number, the soda anthraquinone process gave better results compared to that of the kraft process. Therefore, it could be concluded that the environmentally friendly soda-anthraquinone process was suitable for pulping of OPT.

\section{Bleaching of Pulp}

Elemental Chlorine Free (ECF) bleaching process was applied to Sabah undepithed and depithed (SU and SD) pulps by using five stages bleaching process i.e. ODEoDnD sequence. The bleaching sequence was intended to reduce organochlorine compounds in the bleaching effluent, as indicated in some reports that chlorine dioxide can be used as a substitutionforchlorine. The use of oxygen delignification (the first stage) was aimed to remove a substantial fraction of the lignin in unbleached pulp (Gomes, Jameel and Colodette, 2018). Results of bleaching of Sabah OPT pulp is presented in Table 7.

Bleaching of pulps from undepithed Sabah OPT (SU-UKP, Figure 1) yielded in bleached pulps (SU-BKP) with yields in the range of 24.67$26.73 \%$, brightness in the range of $73.10-78.00 \%$ GE, and dirt content in the range of 20.65-31.00 $\mathrm{mm}^{2} / \mathrm{m}^{2}$ (Table 7). While bleaching of SD pulp gave lower yields of about $26 \%$, brightness in the range of $76.00-79.20 \% \mathrm{GE}$, and dirt in the range of $23.50-58.00 \mathrm{~mm}^{2} / \mathrm{m}^{2}$.

In general, yield based on the original raw material are lower than $30 \%$. The low yield possibly due to decomposition of the raw material begins. These could also be seen at the results of chemical components analysis, i.e. the soluble component in $1 \% \mathrm{NaOH}$, in hot water and in cold water were higher than those of wood. Particularly for depithed bleached pulps, the low yield might also be due to the low depithing yield, i.e.an average of $57.07 \%$. 


\section{Evaluation of Physical Properties}

\section{a. Pulp made from Sabah OPT}

The physical properties of pulps made from Sabah OPT at the freeness of $40^{\circ} \mathrm{SR}$ are presented in Table 8. Pulping of undepithed Sabah OPT using $15 \%$ and $17 \%$ active alkali gave pulp with significantly higher tensile index than those of pulping using 13\% active alkali (compare: 15/ SU-UKP and 17/SU-UKP vs 13/SU-UKP). But for depithed Sabah OPT, there was no significant differences in resulted from pulping with various active alkali (13/SD-UKP, 15/SD-UKP, and 17/ SD-UKP). These tensile index of pulps made from Sabah OPT were much lower than that of Acacia mangium unbleached pulp.

The burst index of all unbleached pulps from Sabah OPT (undepithed SU-UKP and depithed SD-UKP) did not change with the active alkali of pulping, and they were in the range of 3.5 to $5.7 \mathrm{MN} / \mathrm{kg}$ (Table 8). The burst index of all SUUKP and SD-UKP were significantly lower than that of Acacia mangium. While the tear index of all pulp from Sabah OPT apparently did not change with preparation of feedstock (either SU or SD) and the active alkali of pulping (either 13, 15 or 17\%). Moreover, they were closer to that of Acacia mangium $\left(7.12 \mathrm{Nm}^{2} / \mathrm{kg}\right)$, and much better than that of Leaf Bleached Kraft Pulp specified in SNI 6107:2015 $\left(5.50 \mathrm{Nm}^{2} / \mathrm{kg}\right)$.

In general, the tear index of pulps from Sabah OPT could be improved by bleaching process (Table 8). Even the tear indexes of bleached pulp (SU-BKP and SD-BKP) were significantly higher than that of Acacia mangium pulp. The burst indexes of undepithed pulps were also improved by bleaching process, but they were still lower than that of Acacia mangium pulp. For pulp from depithed feed stocks, no improvement on the burst index was observed.

Unlike the tear and burst index, the tensile index of pulps from Sabah OPT (both undepithed and depithed feedstock) in general decreased due to the bleaching process. Actually, the tensile index of Acacia mangium pulp also decreased significantly due to the bleaching process from 93.00 to $49.20 \mathrm{Nm} / \mathrm{g}$ (Uzair, 1991). Since the decreases in tensile index of unbleached pulps from Sabah OPT were small, the tensile index of bleached pulp of Sabah OPT become higher than that of Acacia mangium pulp, and also higher than that of LBKP, $45 \mathrm{Nm} / \mathrm{g}$ (SNI 6107:2015 Leaf Bleached Kraft Pulp (LBKP)).

\section{b. Pulp made from Lebak OPT}

For Lebak OPT, pulping was applied only to undepithed feedstock. Results of pulping using kraft and soda-anthraquinone processes were already presented in Table 6. Physical properties are presented in Table 9. In general, unbleached pulp of LU (undepithed Lebak OPT) from the kraft pulping had better physical properties than that from the SA process. However, the physical properties of unbleached pulp from Lebak OPT were much lower than that of Acacia mangium pulp, with the exception of the tear index of pulp obtained from the kraft pulping.

Table 8. Tearing, Bursting and Tensile Strength of Sabah OPT Pulp at Freeness of $40^{\circ} \mathrm{SR}$

\begin{tabular}{|c|c|c|c|c|c|c|c|}
\hline \multirow[b]{2}{*}{ No. } & \multirow[b]{2}{*}{ Samples ${ }^{\#}$} & \multicolumn{2}{|c|}{ Tear Index $\left(\mathrm{Nm}^{2} / \mathrm{kg}\right)$} & \multicolumn{2}{|c|}{ Burst Index (MN/kg) } & \multicolumn{2}{|c|}{ Tensile Index (Nm/g) } \\
\hline & & $\begin{array}{c}\text { Unbleached } \\
\text { (-UKP) }\end{array}$ & $\begin{array}{c}\text { Bleached } \\
\text { (-BKP) }\end{array}$ & $\begin{array}{c}\text { Unbleached } \\
\text { (-UKP) }\end{array}$ & $\begin{array}{l}\text { Bleached } \\
\text { (-BKP) }\end{array}$ & $\begin{array}{c}\text { Unbleached } \\
\text { (-UKP) }\end{array}$ & $\begin{array}{c}\text { Bleached } \\
\text { (-BKP) }\end{array}$ \\
\hline 1. & $13 / \mathrm{SU}-$ & 7.56 & 8.62 & 4.19 & 4.68 & 47.23 & 51.15 \\
\hline 2. & $15 / \mathrm{SU}-$ & 6.50 & 7.92 & 3.53 & 5.00 & 53.74 & 53.08 \\
\hline 3. & $17 / \mathrm{SU}-$ & 7.77 & 9.10 & 3.86 & 4.49 & 50.40 & 50.56 \\
\hline 4. & 13/SD- & 7.00 & 8.76 & 4.81 & 4.68 & 64.25 & 51.25 \\
\hline 5. & $15 / \mathrm{SD}-$ & 7.75 & 9.15 & 5.13 & 4.79 & 59.39 & 58.06 \\
\hline 6. & $17 / \mathrm{SD}-$ & 7.05 & 8.41 & 5.67 & 4.82 & 64.00 & 56.07 \\
\hline 7. & Acacia mangium pulp* & 7.38 & 7.12 & 7.10 & 5.24 & 93.00 & 49.20 \\
\hline 8. & Leaf Bleached Kraft Pulp ${ }^{* *}$ & & 5.50 & & 2.50 & & 45.00 \\
\hline
\end{tabular}

Note: *) see Legend in Figure 1; *(Uzair, 1991); ${ }^{*}$ SNI 6107:2015 - Leaf Bleached Kraft Pulp (LBKP)

Source: Pratiwi, et al., (2016) 
Table 9. Tearing, Bursting and Tensile Strength of Unbleached Pulp from Lebak OPT at Freeness of $300 \mathrm{~mL} \mathrm{CSF}$

\begin{tabular}{clccc}
\hline No. & Sample ${ }^{\sharp}$ & $\begin{array}{c}\text { Tear Index } \\
\left(\mathrm{Nm}^{2} / \mathrm{kg}\right)\end{array}$ & $\begin{array}{c}\text { Burst Index } \\
(\mathrm{MN} / \mathrm{kg})\end{array}$ & $\begin{array}{c}\text { Tensile Index } \\
(\mathrm{Nm} / \mathrm{g})\end{array}$ \\
\hline 1. & 13/LU-UKP & 8.70 & 3.30 & 37.0 \\
2. & 15/LU-UKP & 9.20 & 3.60 & 36.0 \\
3. & 17/LU-UKP & 6.90 & 3.70 & 38.0 \\
4. & 13/LU-USP & 6.80 & 3.30 & 28.0 \\
5. & 15/LU-USP & 6.70 & 4.20 & 35.0 \\
6. & 17/LU-USP & 7.50 & 3.40 & 46.0 \\
7. & Acacia mangium pulp & 7.38 & 7.10 & 93.0 \\
\hline
\end{tabular}

Note: \#) see Legend in Figure 1; * (Uzair, 1991)

Source: Pratiwi, et al., (2016)

\section{Conclusions}

Possibility of oil palm trunk as a source of fiber for pulp has been studied experimentally. In term of their physical and morphological properties, OPT had the potency to be developed as raw material for paper pulp to substitute for wood fiber. The physical properties of OPT pulps were comparable to that of pulp from Acacia mangium which was commonly used as raw material for pulp. With respect to the bleachability and physical properties, pulping of Lebak OPT using kraft or soda-anthraquinone process with active alkali of $15 \%$ were considered as optimum condition. In term of screened yield and Kappa number, the soda anthraquinone process gave better results compared to that of the kraft process. It could be concluded that the environmentally friendly sodaanthraquinoneprocess was suitable for pulping of OPT.Depithing on Sabah OPT with original high pith content could increase physical propertiesof pulp. ECF bleaching with ODEoDnD sequence on pulps from Sabah OPT gave satisfactory results with respect to the physical properties. Since Sabah OPT had high pith content, the yields of bleached pulp were relatively low, i.e. in the range of 24.67 $26.73 \%$. However, the physical properties of the bleached pulps from undepithed or depithed Sabah OPT were higher compared to those of the LBKP as that specified in SNI.

\section{Acknowledgment}

We would like to thank to Sandwell Inc. for the cooperative research on the utilization of oil palm trunk. We also appreciate the discussion with researchers and technical support from technician in the Centre for Pulp and Paper.

\section{References}

Aljuboori, A. H. R. (2013) 'Oil Palm Biomass Residue in Malaysia: Availability and Sustainability', International Journal of biomass \& renewables OIL.

Awalludin, M. F. et al. (2015) 'An overview of the oil palm industry in Malaysia and its waste utilization through thermochemical conversion, specifically via liquefaction', Renewable and Sustainable Energy Reviews. doi: 10.1016/j. rser.2015.05.085.

Aziz, M. et al. (2017) 'Advanced power generation using biomass wastes from palm oil mills', Applied Thermal Engineering. Pergamon, 114, pp. 1378-1386. doi: 10.1016/J. APPLTHERMALENG.2016.11.031.

Daud, W. R. W. and Law, K. N. (2010) 'Oil Palm Fibers as Papermaking Material: Potentials and Challenges', BioResources, 6(1), pp. 901-917. doi: 10.15376/biores.6.1.901-917.

Direktorat Jenderal Perkebunan (2014) Tree Crop Estate Statistic of Indonesia 2013 - 2015: Palm Oil. Available at: http://ditjenbun.pertanian. go.id/tinymcpuk/gambar/file/statistik/2015/ SAWIT 2013 -2015.pdf.

Erwinsyah, E., Afriani, A. and Kardiansyah, T. (2015) 'Potensi dan peluang tandan kosong sawit sebagai bahan baku pulp dan kertas: Studi kasus di Indonesia', JURNAL SELULOSA, 5(02), pp. 79-88. doi: 10.25269/jsel.v5i02.79.

Garcia-Nunez, J. A. et al. (2016) 'Evolution of palm oil mills into bio-refineries: Literature review on current and potential uses of residual biomass and effluents', Resources, Conservation and Recycling, 110, pp. 99-114. doi: 10.1016/j. resconrec.2016.03.022. 
Gomes, V. J., Jameel, H. and Colodette, J. L. (2018) 'Effects of lignin chemistry on oxygen delignification performance', Tappi Journal, 17(7), pp. 373-381. doi: 10.32964/ TJ17.07.373.

Hambali, E. and Rivai, M. (2017) 'The Potential of Palm Oil Waste Biomass in Indonesia in 2020 and 2030', in IOP Conference Series: Earth and Environmental Science. IOP Publishing, pp. 1-9. doi: 10.1088/17551315/65/1/012050.

IRDCI (1999) The Utilization of Oil Palm Plantation Residue as Raw Material for Pulp.

Joedodibroto, R. (2000) 'Palm Plantation Residues as An alternative Source of Cellulose Raw Material for The Pulp and Paper Industry', in Indonesian Natural Resources for Pulp and Paper. Bandung, pp. 41-48.

Mamiński, M. et al. (2016) 'Enhancement of technical value of oil palm (Elaeis guineensis Jacq.) waste trunk through modification with 1,3-dimethylol-4,5-dihydroxyethyleneurea (DMDHEU)', European Journal of Wood and Wood Products. doi: 10.1007/s00107016-1086-2.

Pratiwi, W., Sugiharto, A. and Sugesty, S. (2001) Development of Oil Palm Trunk for Paper Pulp.

Pratiwi, W., Sugiharto, A. and Sugesty, S. (2016) 'Pulping of Oil Palm Trunk using Enviromentally Process', in Proceedings of International Symposium $2^{\text {nd }}$ REPTech. Bandung, pp.291-299.
Risdianto, H., Kardiansyah, T. and Sugiharto, A. (2016) 'Empty Fruit Bunches for Pulp and Paper Production: The Current State in Indonesia', Journal of Korea TAPPI, 48(6), pp. 253-3200. doi: 10.7584/ JKTAPPI.2016.12.48.6.25.

Sarwar Jahan, M., Sarkar, M. and Rahman, M. M. (2017) 'Mixed Cooking of Bamboo with Hardwood', Cellulose Chem. Technol., 51(4), pp. 307-312.

Singh, P. et al. (2013) 'Using biomass residues from oil palm industry as a raw material for pulp and paper industry: potential benefits and threat to the environment', Environment, Development and Sustainability, 15(2), pp. 367-383. doi: 10.1007/s10668-012-9390-4.

Sulaiman, O. et al. (2012) 'The potential of oil palm trunk biomass as an alternative source for compressed wood', BioResources. doi: 10.15376/biores.7.2.2688-2706.

Uzair, et al (1991) 'Pengaruh Umur Kayu Acacia mangium terhadap Sifat-sifat Pulp untuk Kertas (The Influence of Acacia mangium Wood Ages on the Properties of Paper Pulp) 1991', in Simposium Selulosa dan Kertas XII (Symposium on Cellulose and Paper XII). 